Article

\title{
Social Learning in Multilevel Flood Risk Governance: Lessons from the Dutch Room for the River Program
}

\author{
Jacomien den Boer ${ }^{1}$, Carel Dieperink ${ }^{1, *}$ (D) and Farhad Mukhtarov ${ }^{2,3}$ \\ 1 Copernicus Institute of Sustainable Development, Utrecht University, P.O. Box 80115, \\ 3508 TC Utrecht, The Netherlands; denboerjacomien@gmail.com \\ 2 International Institute of Social Studies (ISS), Erasmus University Rotterdam, Kortenaerkade 12, \\ 's-Gravenhage; 2518 AX The Hague, The Netherlands; mukhtarov@iss.nl \\ 3 Institute of Water Policy, Lee Kuan Yew School of Public Policy, National University of Singapore, \\ 469C Bukit Timah Road, \#02-03C, Singapore 259772, Singapore \\ * Correspondence: c.dieperink@uu.nl; Tel.: +31-30-253-2737
}

Received: 2 September 2019; Accepted: 25 September 2019; Published: 28 September 2019

\begin{abstract}
Although social learning is a key element of multilevel flood risk governance, it is hardly studied. This paper addresses this knowledge gap. The paper aims to identify enabling conditions for social learning in multilevel flood risks governance arrangements. We first conceptualize social learning and draw up a conceptual framework consisting of enabling conditions for social learning, using the literature on adaptive co-management, sustainable land and water management, and integrated flood risk management. Next, we apply this framework to analyze social learning in the context of the Dutch Room for the River program. Our interview results reveal that social learning about integrated flood protection measures took place at multiple levels. We found that a strong personal commitment to learning and mutual interpersonal trust in working groups are key conditions for successful social learning. Based on our analysis, we conclude with some recommendations for enhancing social learning processes in future flood protection programs.
\end{abstract}

Keywords: social learning; integrated flood risk management; Room for the River program; multilevel governance

\section{Introduction}

Population growth and increased socioeconomic activity in floodplains, combined with more recent effects of climate change, are important factors in the increase of flood risks [1,2]. A gradual shift is visible in flood management across a number of countries: from flood defense based on 'fighting against water' to flood risk management and 'living with water' [3,4]. This shift in flood protection measures over the last decades is known as integrated flood risk management (IFRM) and is increasingly adopted as the basis for a number of flood protection programs, e.g. in the Netherlands, the United Kingdom, and other countries [5-7]. Successful coexistence of the natural phenomenon of flooding and the human population depends largely on the organization of the governmental system and the decision-making process among mandated stakeholders. For IFRM, multiple actors at multiple policy levels need to collaboratively design and implement new flood risk management policies $[6,8]$. An integrated approach to flood risk governance includes both engineering solutions and spatial planning projects that are combined and aligned, such as spatial development, housing, economic activity, as well as governance solutions such as aligning funding from different policy domains and collaboration between multiple stakeholders [9-11]. IFRM can therefore, be seen as a multilevel and multistakeholder governance practice [12-14]. 
Growing scholarly interest in collaborative modes of governance stresses the complexity and uncertainty inherent to such institutional arrangements [14-18]. Collaborative arrangements are network structures where participating organizations depend on each other to achieve tasks that reach beyond their individual capacities [19]. Such interdependence requires the capacity for social learning for success and endurance of collaborative and multilevel arrangements. This realization has led to blossoming literature on social learning for collaborative institutions $[10,17,20-25]$. This literature discusses social learning in a natural resources management context. However, studies on social learning in the context of multilevel flood risk governance are rare, and we have not yet been confronted with studies that specify the conditions that enable social learning in flood risk governance.

This article deals with this gap in the literature by presenting a conceptual framework to study social learning in the context of flood risk governance arrangements, which is then applied in a case study. The case study concerns social learning in the Room for the River program, a multilevel flood risk management program in the Netherlands. The case involves multiple and diverse governmental actors, working collectively on flood risk management in the Netherlands.

Sections 2 and 3 reflect on the literature and conceptualize social learning for multilevel flood risk governance. For the conceptualization of social learning, we draw from literature on learning and organizational theories, which are related to the natural resources management domain. Suitable literature was found using Google Scholar and Scopus, by searching for different combinations of keywords like 'social learning', 'multi-level water governance', 'adaptive co-management', 'integrated flood risk management', 'learning process', 'collaborative learning' and 'multiple-loop learning'. In Section 4, the methods applied in the empirical part of the paper are explained. In Section 5, we present the results of the case study, leading to a discussion and conclusion in Section 6.

\section{Conceptualizing Social Learning: Three Debates}

Social learning is a key concept for adaptive co-management, multilevel governance, and integrated flood risk management (see e.g., $[10,13,15-18,20,21,26,27])$. Both complementary and overlapping definitions for social learning are found in these strands of literature. Social learning appears to be a highly debated concept in literature. Three debates can be distinguished, which concern the relation between individual and social learning (e.g., [19,21,28], learning as an outcome or as a process $[15,25,29,30]$, and learning-levels and learning loops [6,31,32]).

A first important debate in the literature is the distinction between social learning as different from individual learning $[25,28,33]$. Scholars have maintained a distinction between individual learning and social learning $[14,19,21,34]$ in which the latter is based on deliberation and produces qualitatively different forms of decision-making as opposed to individual learning [35-37]. This line of research, for example, ventured to understand how individual learning may become social learning, as in the case of flood risk governance in the UK (e.g., [38]). As opposed to individual learning, the concept of social learning relates to notions of 'learning communities' and 'communities of practice' (e.g., [20]). These communities consist of people that share a common concern and pursue knowledge through regular interaction, based in practice [20]. It goes beyond individual learning (a football player improving his personal skills) or individuals learning together (football players who train their personal skills during team practice). Social learning here is understood to be a process of change at the group level [39] in which people learn from each other, which benefits the wider socioecological systems they operate in (e.g., river basins or community forests). For learning to be social, a change in understanding must occur at a larger scale, through social interaction [14,21]. Thomas and Allen [40] argue in a similar way for organizational learning, from which social learning is partially derived: 'while organizations learn through individual learning, organizational learning is not a cumulative result of individual learning. Rather, organizations learn when discoveries, evaluations, and insights by individuals are successfully embedded in the organization's mental models or cognitive systems and memories' (p. 125). To other scholars, however, collective learning may originate only when individual members of a collective learn and hence, is merely a sum of individual learning [41-43]. Heikkila and 
Gerlak [44] (p. 486), in turn, recognize the complexity of separating individual and collective learning in empirical settings and accept that learning may happen 'at multiple levels in collective settings, from individuals, to groups, organizations, and networks, and these levels are linked by dynamic social processes of producing and sharing knowledge' [44]. According to these scholars, the focus must be placed on the processes and products of learning rather than the relationship between the individual and collective learning, a view which is supported by Suskevics et al. [25].

Another area where a consensus is yet to emerge is in the debate on whether learning should be seen as a process or as an outcome $[21,25,29]$. Learning outcomes, or products, 'can include new shared ideas, strategies, or actions among the parties involved in the learning process' [19] (p. 4). Social learning outcomes are numerous (e.g., $[15,25,29,32])$. Among others, increased understanding of key issues, trust-building, acquisition of factual knowledge, and social skills are the results of social learning processes. The learning process, subsequently, is 'the set of actions that allow new information or knowledge to be acquired, processed and shared, and transferred across individuals within a group' [19] (p. 3). Mostert et al. [15] (p. 1,2) perceive social learning as a process within a specific context, which includes both a natural context (ecology, geography) and a social context (economy, culture, governance system). A learning process emerges when stakeholders realize they are interdependent in pursuing a goal or policy, which means that individual action will yield less or no result, and collaboration is thus necessary. The learning process can be initialized by the stakeholders or by an external party. According to Mostert et al. [15], the learning process involves 'the development of trust, joint problem definition, joint fact-finding, the development and assessment of different alternatives, joint decision-making, and joint planning for implementation' (p. 2). Process outcomes are, e.g., better relations, increased trust, and empowerment of stakeholders. They emphasize the participatory character of the process. Similarly, Bos et al. [30] define social learning as 'a collective process enabling change in a situation, as opposed to social learning as an outcome or 'emergent property' of a process to change a situation' (p. 399). The notion of social learning as a process points to 'actors developing shared meanings, values, and understanding through interaction, which provides the basis for joint future action' ([29,45] are quoted from [31]).

The third debate in the literature concerns the relative importance of various contextual factors in influencing the process and outcomes of social learning, which is a growing body of empirical literature that discusses case studies in individual and comparative settings. Medema et al. [32] and Pahl-Wostl [31] argue that learning processes are largely influenced by the governance system in which they are embedded. The governance structure includes 'the pertinent legal and organizational framework as well as the cultural and socioeconomic environment' [31] (p. 4). Social learning can be described as a multiscale process, hence learning can occur at multiple levels of agent interaction [31,32]. The macro-level is the level of the governance structure at societal level. The meso-level is at the level of actor networks, or organized stakeholder groups. The micro-level is at the level of collaboration processes between stakeholder representatives of flood protection authorities (i.e., actual meetings). According to Pahl-Wostl et al. [31], the multiparty collaboration processes are the 'nuclei' of the learning process (p. 5). When transferring this multiscale learning process to a geographical level, Huitema et al. [16] advocate a bioregional approach (i.e., at watershed level) for water governance, reflecting the micro-level of regional multi-party collaboration processes. With regard to conditions that explain learning processes, they will also pertain to the micro-level.

In this paper, we aim to contribute to these three debates by analyzing an empirical case in order to reveal what factors influence social learning in the context of multilevel flood risk governance.

\section{A Framework of Factors that Influence Social Learning}

To study learning in the setting of multilevel flood risk governance, we adopt the following definition for social learning (based on e.g., $[15,17,18,20,21,23,27,46]$ :

Social learning is a process of change in understanding, that goes beyond the individual, at the micro-level of multi-party collaboration, aiming at collective action for integrated flood protection. 
By reviewing the abovementioned learning literature, we have found that most of the factors that will likely influence the learning process can be categorized into 4 categories-individual attributes, collaborative arena factors, organizational factors, and external context factors (see also [33]). Combined, these factors provide a framework that can be used to analyze learning processes (Figure 1).

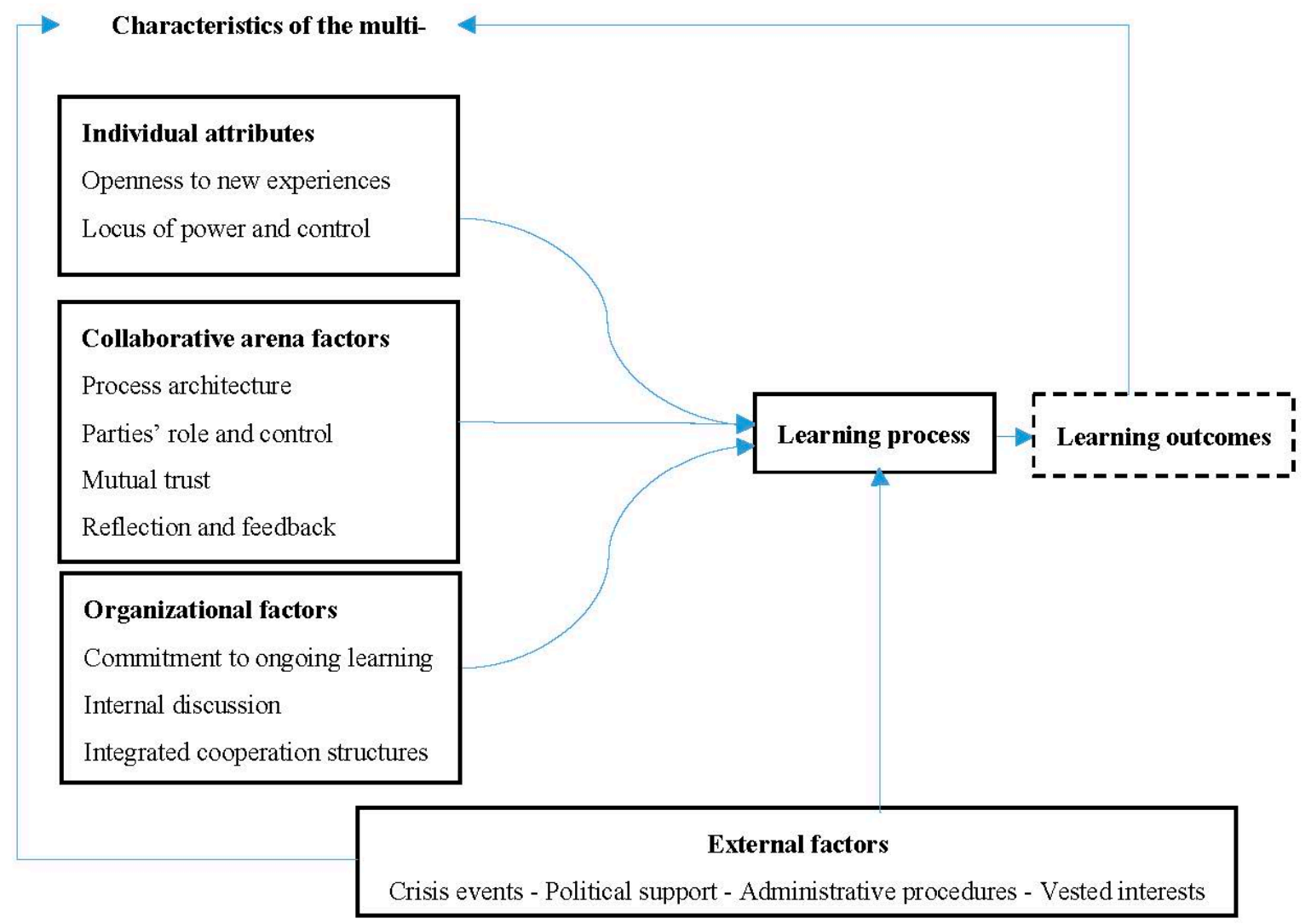

Figure 1. A framework for analyzing social learning.

\subsection{Individual Attributes}

Individual attributes (see Table 1) are described as the 'the micro-level factors relating to the reactions to change efforts by stakeholders and individuals involved in the learning process' or 'the psychological predispositions of the individuals experiencing change' [32] (p. 26); [47] (p. 107). Individuals and their characteristics form the basis through which learning is manifested [48]. First of all, a commitment to ongoing learning is an important characteristic of learning [49,50]. Individuals with personality traits like tolerance of ambiguity and openness to new experiences are better able to learn from experiences and are less eager to have a confirmation bias, i.e., searching for information that confirms their beliefs. The extent to which a person is flexible and open-minded is an important attribute for learning: when the individual has little resistance to changing the way things are done, he or she is more eager to learn from this situation [51-53]. Related to that is the capability for self-reflection, which is crucial for multiloop learning $[17,49,54-56]$ and the individual's perception and awareness of his own role and abilities to exercise control in certain situations, or locus of power and control [51,57]. Mostert et al. [15] stress that a legitimate process in which participants are willing to learn require high professional competence and motivation. Social skills, in the form of sticking to rules and principle of dialogue and interaction come into play when differing views and perceptions of parties may lead to conflict [15]. When participants address each other in a respectful manner, they are more likely to agree on core issues regarding the policy process, which improves learning. A factor that explains successful learning is previous experience with a multiparty approach [15]. A positive experience will make it more likely that participants are willing to learn from other participants. 
Table 1. Individual attributes influencing the social learning process.

\begin{tabular}{lll}
\hline \multicolumn{1}{c}{ Individual Attributes } & \multicolumn{1}{c}{ Description } & \multicolumn{1}{c}{ Authors } \\
\hline Openness to new experiences & $\begin{array}{l}\text { Commitment to ongoing learning, capability for } \\
\text { self-reflection, flexible and open-minded attitude } \\
\text { to issues at hand, tolerance of ambiguity in policy } \\
\text { problems and solutions }\end{array}$ & {$[15,19,47,49-52,54,56,58]$} \\
\hline Locus of power and control & $\begin{array}{l}\text { Ability to control and influence one's } \\
\text { environment and hence feel engaged in policy } \\
\text { processes }\end{array}$ & {$[15,51,57]$} \\
\hline Social skills & $\begin{array}{l}\text { Ability to communicate, listen and express one's } \\
\text { opinion, and follow the rules of an open dialogue }\end{array}$ & {$[15,51]$} \\
\hline $\begin{array}{l}\text { Experience with multiparty } \\
\text { approaches }\end{array}$ & $\begin{array}{l}\text { Previous experience with multilevel governance } \\
\text { policy arenas }\end{array}$ & {$[15]$} \\
\hline
\end{tabular}

\subsection{Collaborative Arena Factors}

Collaborative arena factors (see Table 2) refer to the way the participatory process is organized and which actions and directions are taken during a policy planning and implementation phase. It is widely recognized that the structure of the institutional arrangement is an important explanatory factor in the occurrence or absence of social learning $[19,34]$. These factors determine if participants feel respected and heard [32]. Involving all relevant stakeholders in a participatory process for developing and implementing new policies is important [59]. With regard to collaboration, crucial factors in the participatory process are mutual trust, goodwill, and mutual understanding, as is acknowledged interdependency [58]. If lacking, learning is unlikely to occur as common understanding and goals will not be reached [60]. Openness and legitimacy of the participatory process through continuous feedback on the process (e.g., through distribution of meeting records, background documents, questionnaires) is important to create trust and goodwill $[15,32]$. The overall process architecture is an important condition in this respect. Frequent interaction among stakeholders is crucial for social learning [15]. Clear perspective and direction for feedback are crucial for multiloop learning, as the feedback navigates the process toward desired goals. It is also crucial that participants have clear expectations on the participatory process. A joint planning approach can facilitate this and also increase the transparency of the process, which in turn increases trust and goodwill [15,59]. Role and control of parties involved explaining what influence the role a party or representative has in the collaboration process and what the position of a party is relative to other parties. Related to that is having a neutral organizer or leader who facilitates and presides the participatory process so as to enable fair balancing of interests. This helps to build a democratic and enabling environment for learning processes, in which appropriate meeting formats and extended engagement (repeated and frequent interactions, field trips, bilateral contacts) facilitate trust, collective meaning, constructive conflict solving, that in turn help participants to create a sense of ownership and commitment toward the learning process [15,31,59]. Besides these rather intangible factors, available resources in the form of budget, time, and information are essential as well in order to facilitate a successful learning process. Feedback and reflection, provided there is a clear goal, create a loop in which participants can learn from their previous experiences, and consequently optimize the collaborative process. Framing and reframing of how a policy problem is perceived can open up individual perspectives, thereby creating win-win situations [61,62]. This results in improved mutual trust and better relations, factors previously marked as crucial for social learning. A final factor, communication, both internal (between members of the working groups) and external (to external parties or home organizations), is crucial for diffusion of information throughout the working group and to other organizations. 
Table 2. Collaborative arena factors influencing the social learning process.

\begin{tabular}{lll}
\hline Collaborative Arena Factors & \multicolumn{1}{c}{ Description } & Authors \\
\hline Process architecture & $\begin{array}{l}\text { Frequent interactions of working groups with appropriate } \\
\text { meeting formats, joint planning and a clear and shared } \\
\text { perspective, extended engagement, a transparent and } \\
\text { legitimate process for a democratic and enabling environment. }\end{array}$ & {$[15,17,54,55,58,59,61,63-66]$} \\
\hline $\begin{array}{l}\text { Role and control of parties } \\
\text { involved }\end{array}$ & $\begin{array}{l}\text { A neutral organizer or leader that includes all the relevant } \\
\text { stakeholders in the process. }\end{array}$ & {$[15]$} \\
\hline $\begin{array}{l}\text { Mutual trust, goodwill and } \\
\text { understanding }\end{array}$ & Acknowledged interdependency, good working relations & {$[51,54,58]$} \\
\hline Reflection and feedback & $\begin{array}{l}\text { Continuous feedback on process and content, and framing and } \\
\text { reframing of issues and goals. }\end{array}$ & {$[15,58,66-72]$} \\
\hline Available resources & Knowledge, financial budget, time. & {$[15,55,58]$} \\
\hline Communication & $\begin{array}{l}\text { Internal organizational communication as well as external } \\
\text { communication between different working groups. }\end{array}$ & {$[15,58]$} \\
\hline
\end{tabular}

\subsection{Organizational Factors}

Organizational context factors (see Table 3) are preexisting forces in the governance system, which includes the internal context of the participants' home organization. Equality and balanced interests, or the lack thereof, as well as (a lack of) internal conflict on interests, are often mentioned as a prerequisite for social learning or frustrating learning [15], as equal treatment of and opportunities for participating and influencing the policy process will positively influence the learning process. Entering a long-term working relationship, thereby creating a horizontally and vertically integrated cooperation structure, brings the context of the participatory process and the home organization together [15,32]. It prevents contradictory decisions or recommendations in the internal context of an organization. Integration of knowledge and information sources through advanced information management is important in this respect. Bridging organizations, learning platforms facilitate institutional interplay, stimulate learning in the participatory process by providing connection between different scale and higher- and lower level organizations, thereby enabling the integration of knowledge $[16,59,70]$. According to Cash et al. [73], knowledge is stored and perceived differently at different levels, based on differing beliefs of what is credible and legitimate knowledge and the nature of the problem for which policy is developed and implemented. Cross-level linkages that allow access to validated information makes the information trustworthy and links the participants through the use of the information [74]. Organizational commitment to learning and overall involvement of parties in the process is an important condition for social learning. Continuity, facilitated by, e.g., transfer of information to other representatives of the same organization, fosters social learning [15]. This also creates a sense of belonging for the participants that feedback the process outcomes in their own organizations. Changing staff or participants during the participatory process hinders social learning, as knowledge and experience is lost. Consequently, being a reliable and consistent stakeholder in the policy formulation and implementation processes is important for a person's credibility and the extent to which other parties are willing to accept, e.g., new information [32]. 
Table 3. Organizational factors that influence the social learning process.

\begin{tabular}{lll}
\hline \multicolumn{1}{c}{ Organizational Factors } & \multicolumn{1}{c}{ Description } & Authors \\
\hline Commitment to ongoing learning & $\begin{array}{l}\text { Internal commitment to learning as a way to improve } \\
\text { organizational practice. }\end{array}$ & {$[15,74]$} \\
\hline Internal discussion on interests & $\begin{array}{l}\text { Agreement on internal goals and interests, equality } \\
\text { and balanced interests. }\end{array}$ & {$[15,58]$} \\
\hline $\begin{array}{l}\text { Horizontally and vertically } \\
\text { integrated cooperation structures }\end{array}$ & $\begin{array}{l}\text { Institutional interplay in the internal context of the } \\
\text { organization, bridging organizations, integration and } \\
\text { synthesis of knowledge. }\end{array}$ & {$[17,46,58,59,70,74-78]$} \\
\hline $\begin{array}{l}\text { Integration of knowledge and } \\
\text { information sources }\end{array}$ & $\begin{array}{l}\text { Advanced information management and a sound } \\
\text { knowledge base for efficiency in policy development. }\end{array}$ & {$[58-60,79-84]$} \\
\hline Involvement of parties & $\begin{array}{l}\text { Reliability and consistency of partners, continuity of } \\
\text { staff in organizations. }\end{array}$ & {$[15,50,54]$} \\
\hline
\end{tabular}

\subsection{External Factors}

External context factors (see Table 4) are preexisting conditions and forces, but ones that are difficult to control by a specific governance regime [32]. Abrupt periods of change or crisis events (e.g., flooding or elections) are important drivers for change and hence for learning [15]. Such crises may turn out to be windows of opportunity for bringing about political support and supportive regulatory changes, which in turn can alter lengthy administrative procedures that hinder social learning [32]. Vested interests may hinder social learning, since existing regulatory frameworks are supported, allowing little room for lessons in social learning processes [15]. Existing laws and regulation also affect learning processes due to inflexible working processes that leave little room for change.

Table 4. External context factors influencing the social learning process.

\begin{tabular}{lll}
\hline \multicolumn{1}{c}{ External Factors } & \multicolumn{1}{c}{ Description } & \multicolumn{1}{c}{ Authors } \\
\hline Crisis event (calamity, elections) & $\begin{array}{l}\text { Events like floods or election can disrupt } \\
\text { collaborative processes. }\end{array}$ & {$[15,51,58,60,79,85]$} \\
\hline Political support & Supportive regulatory and political framework. & {$[15,51,55,60,79,85,86]$} \\
\hline Administrative procedures & Lengthy and complex procedures, e.g., permits. & {$[15]$} \\
\hline Existing laws and regulations & Path dependency, inflexible working processes. & {$[15]$} \\
\hline
\end{tabular}

\section{Methods: Case Characteristics and Data Collection}

The framework presented in the previous chapter is used for studying social learning in the context of multilevel flood risk governance. An eye-catching example of multilevel flood risk governance is the Dutch Room for the River (RftR) program. Aim of the program is to increase the buffering capacity of the Rhine river branches (Waal, IJssel and lower Rhine) in case of high water levels. This is done by creating more room for rivers and their branches through making more space for water by, e.g., dike relocation and the lowering of floodplains (Figure 2). By doing this, the Netherlands can deal with higher water levels $\left(16.000 \mathrm{~m}^{3} / \mathrm{s}\right.$ instead of from $\left.15.000 \mathrm{~m}^{3} / \mathrm{s}\right)$ that may enter the country at Lobith, where the river Rhine crosses the German-Dutch border [87]. 


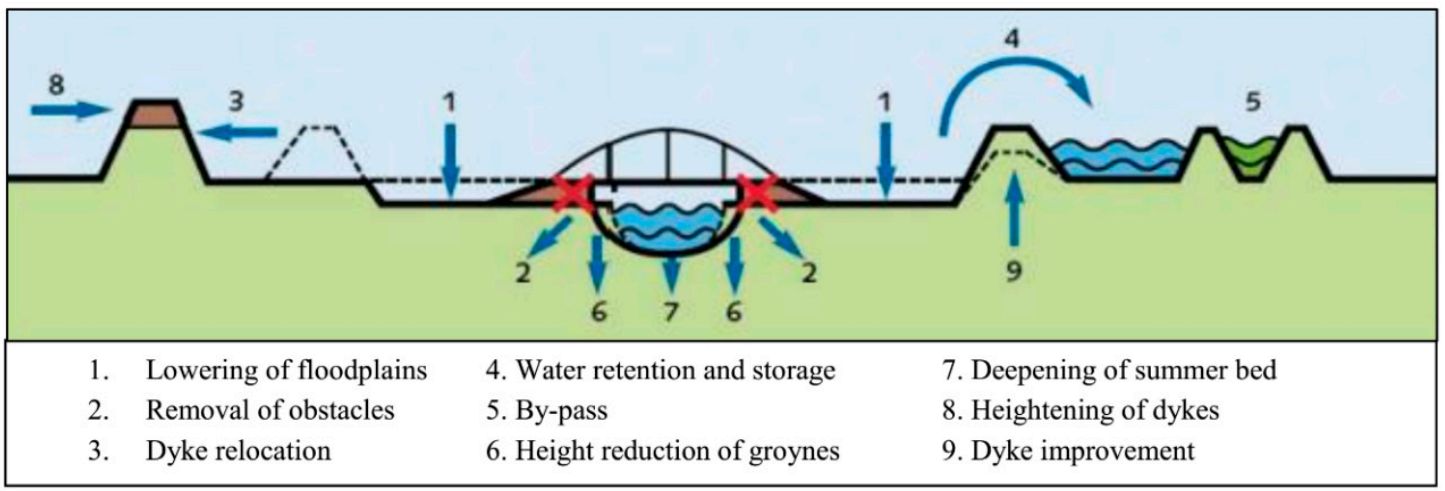

Figure 2. Measures applied to create more room for river in the Room for the River program. Adapted from [13].

The program consisted of 34 separate projects, with a total budget of $€ 2.3$ billion. It had a dual goal: both flood protection and spatial quality in the riverine area are increased, by means of, e.g., dike replacement and nature development. Hence, multiple disciplines and organizations are involved in designing and implementing the measures for making room for the river. It is exemplary for a multilevel governance program, as multiple actors, multiple disciplines, and multiple policy and decision-making levels are represented in the program both in the design and executive phase $[13,88]$. The program involved numerous formal and informal relationships among a group of organizations that agreed to achieve certain goals in a set period of time and a fixed budget. Nevertheless, competing demands and interests occurred.

RftR was initiated in 2000 and was finalized in mid-2017 [89]. From 2008/2009 until approximately 2012, the chosen projects were meticulously prepared by an extensive multilevel stakeholder collaboration process (including e.g., Rijkswaterstaat, provinces, water authorities, municipalities, citizens, societal organizations (e.g., nature conservation organizations, environmental groups)). Early involvement of politicians and non-governmental stakeholders was deemed crucial for establishing commitment and support [88]. The program had a long duration (2000-2017) which allowed for learning-by-doing [10], but it also requires an adaptive approach to deal with ongoing changes in both the internal and external context of the program, like changing stakeholder interests and configuration, socioeconomic developments (e.g., elections or economic crises), and new scientific findings [90]. Two government ministries (Ministry of Economic Affairs and the Ministry of Infrastructure and Environment, I\&E), together with eight water authorities, seven provinces, and thirty municipalities, were responsible for the execution of the projects in the program [91]. Fifteen out of 34 projects are executed by Rijkswaterstaat, the remaining 19 are executed mainly by water authorities, and some by provinces and municipalities.

In order to find out what learning has taken place during the Room for the River process, two rounds of in-depth, semi-structured, face-to-face interviews $(\mathrm{N}=16)$ were conducted with policy officers of governmental organizations involved in the RftR program (Rijkswaterstaat, Provinces, municipalities, water authorities). These governmental organizations were chosen since in the Netherlands they have the mandate and responsibility for flood risk management, as opposed to civil organizations or interest groups. The first round of interviews was instrumental in activating the respondents in recalling learning processes since they occurred over long periods of time. The second round of interviews (with the same interviewees) was based on a topic list that was adapted from the conceptual framework (Figure 1) including the possibility to add conditions that respondents felt were instrumental to social learning processes and were not mentioned in the initial framework. We assumed that respondents were able to clarify and distinguish the lessons learned and the different conditions that affected their learning processes. By asking follow-up questions during and after the interviews, we managed to get a better insight into the respondents' perceptions. 
Within the program, respondents were selected based on their involvement in either an administrative guidance group (ABG) or a licensing authority working group (AWBG) or both. The first was mainly involved in designing projects, whereas the latter is responsible for the permit procedures for, e.g., soil removal. These working groups were chosen as the platform for selecting respondents because the multilevel governance arrangement is institutionalized in these structures, i.e., all layers of governmental parties in the Dutch water sector are represented in these working groups. Represented are water authorities, Provinces, municipalities, Rijkswaterstaat RftR program directorate (PDR), and Rijkswaterstaat regional offices.

Supplementary to interviews, mid-term and end-term reviews commissioned by the PDR were used to gain insight into the overall RftR program and its performance on, e.g., timing and budget [92-95].

The interview results were transcribed, arranged, and coded using an excel table, which corresponded with the interview topic list: a list of learning outcomes and a list of enabling factors and how they influence learning.

\section{Results}

\subsection{Learning Outcomes}

The learning outcomes we found can be clustered in collective products [19], development of relations, and new shared interests, ideas, and strategies.

Examples of collective products are new strategies for, e.g., permit procedures, the introduction of life cycle costing in the design phase of the projects, strict record-keeping of complex decision-making procedures, and the creation of a bridging organization that facilitates knowledge exchange between projects. Besides, the use of Integrative Project Management (IPM) was introduced during the RftR program and later used in other, non-flood related projects as well. These IPM teams perform five very specific roles with corresponding responsibilities related to major infrastructural projects. The development of relations shows in the frequent so-called 'milestone celebrations', frequent face-to-face meetings, both official and in the field and flexible attitudes in formal operations (e.g., the occurrence of shared debates). Shared meaning shows in the parties' recognition and acknowledgment of one another's interests. At some point, parties were able to bring their own interests to the table, without denying other parties theirs. New strategies show in the early involvement of a broad range of stakeholders in the projects to allow for a joint project, that is broadly supported. Showing the added value of the project and choosing the right party to lead the project in its different phases is a learning outcome that has been instrumental in ensuring the progress of the projects.

\subsection{Learning Process}

The main findings from the interviews suggest that social learning in the Room for the River project is highly influenced by individual attributes and collaborative arena factors, and less by external context and organizational factors, as shown in Table 5.

\subsubsection{Individual Attributes}

Respondents confirmed that openness to new experiences, self-reflection, and flexibility add to a social learning process. Individuals that are open for new experiences are more likely to observe the lessons to be learned and are more willing to change. 'Learning is change' (interviewee 1), 'Every now and then you should take a little distance from your own work, and reflect on what's going well, what you should do different. That is the most important thing. [..] Because if you're not open for learning and change, you won't change' (1). Social skills or the ability to express yourself and formulate interests and arguments is paramount. This skill works in two ways: having the right social skills helps to formulate your own or organizations' point of view in the discussion, but also helps to recognize and formulate viewpoints from other parties or individuals in the collaboration process. It is seen by many as a precondition for collaboration and consequently for learning. 
Table 5. Factors influencing the social learning process in the Room for the River Project.

\begin{tabular}{|c|c|c|c|c|}
\hline $\begin{array}{l}\text { Did This Factor Influence the Social Learning Process } \\
\text { Positively? (i.e., Is the Variable Enabling Social Learning?) } \\
\text { (N = 16) }\end{array}$ & $\begin{array}{l}+ \\
\text { Yes, Positive Influence }\end{array}$ & No, no Positive Influence & $\begin{array}{l}+/- \\
\text { Both a Positive and a Negative Influence }\end{array}$ & $\begin{array}{l}? \\
\text { No Answer }\end{array}$ \\
\hline \multicolumn{5}{|l|}{ Individual attributes } \\
\hline Openness to new experience, self-reflection, flexibility & 16 & 0 & 0 & 0 \\
\hline Locus of power and control & 12 & 1 & 2 & 1 \\
\hline Social skills & 15 & 0 & 0 & 1 \\
\hline Experience with multilevel governance structures & 7 & 7 & 2 & 0 \\
\hline \multicolumn{5}{|l|}{ Collaborative arena factors } \\
\hline Role and control of different parties & 15 & 0 & 0 & 1 \\
\hline Mutual trust & 13 & 0 & 3 & 0 \\
\hline Interdependency & 13 & 1 & 1 & 1 \\
\hline Reflection and feedback & 15 & 1 & 0 & 0 \\
\hline Available resources & 8 & 6 & 2 & 0 \\
\hline Process architecture & 12 & 2 & 2 & 0 \\
\hline Communication & 13 & 1 & 0 & 2 \\
\hline \multicolumn{5}{|l|}{ Organizational factors } \\
\hline Organizational commitment to learning and change & 14 & 0 & 1 & 1 \\
\hline Integration of knowledge and information sources & 9 & 3 & 3 & 1 \\
\hline Horizontally and vertically integrated cooperation structure & 10 & 4 & 0 & 2 \\
\hline Internal conflict of interests & 8 & 4 & 2 & 2 \\
\hline Involvement of stakeholders & 9 & 0 & 6 & 1 \\
\hline \multicolumn{5}{|l|}{ External factors } \\
\hline Crisis events & 7 & 4 & 2 & 3 \\
\hline Administrative procedures & 5 & 8 & 0 & 3 \\
\hline Political support & 10 & 5 & 1 & 0 \\
\hline Existing laws and regulation & 5 & 6 & 0 & 5 \\
\hline
\end{tabular}




\subsubsection{Collaborative Arena Factors}

The role and control of different parties and reflection and feedback is seen by almost all respondents as a positive influence on the social learning process. Mutual trust and interdependency are also seen as preconditions for social learning, although some argue that trust is a precondition for collaboration but not necessarily for learning. Some even argue that a little distrust or suspicion has a positive influence on learning, 'because you learn most of someone who does things differently than you $d o$ ' (interviewee 2). The opposite was also rhetorically addressed: 'Would you learn without trusting someone? I don't think so. So first of all you'll have to trust someone before you can learn anything. That is crucial. But trust is something you earn. And you earn trust by letting go of the details and checks. [... ] So giving trust in fact' (interviewee 3). The importance of trust is explained by most respondents by linking it to a safe environment for learning, in which people trust each other and share their issues. A safe learning environment through mutual trust is seen as a precondition for social learning by many respondents. The score for both a negative and a positive influence on learning is explained by learning when collaboration is not successful. As a respondent explained: 'Collaboration does not always have to be successful in order to learn, you can also learn when collaboration isn't working out. And you might even learn more from that, but not as a group. You'll learn as an individual, but as a group you won't, because everyone has withdrawn in his own island again' (interviewee 2). An additional condition that was mentioned in the interviews which influences the level of trust in a working group is stereotypical thinking. Due to parties having a certain image of each other, or ideas about each other's working processes, stereotypical thinking occurs, which negatively affects the collaboration process and consequently the level of trust in a working group. This is also related to previous experiences with other parties. When starting a new project with the same party, it frequently occurs that the participants start the project with a certain idea about the other parties, which frustrates an open start of the project and creates unrealistic or wrong expectations, which in turn affects the level of trust in a working group. Role and control of parties determine which position in the collaboration process you have, which also shapes the interdependency relation with the other parties. This relation determines what your attitude is toward other parties and delineates different tasks.

Reflection, feedback, and trust have a reciprocal relation, as trust is needed before individuals will give feedback and reflect on the collaborative process. Reflection is a joint activity in which the collaborative process so far or process outcome is reflected, whereas feedback is of a more personal nature, between individuals and their performance. Both yield the same results: explicit lessons to be learned to improve the collaborative process. For the other factors, results are mixed. The process architecture appears to be an important condition influencing social learning. The frequency of meetings, field trips, and extended engagement through bilateral contacts are helpful in formulating expectations and frameworks for the team to work with. It helps to delineate the process and creates the network in which the parties operate and the agreements on which the collaboration is based. Communication, both internal and external, is seen by many as part of the process architecture and a positive influence on social learning. Without communication in the working group, no information or feedback is fed back in the collaboration process, which would hamper social learning. Timing and what to communicate and what not were mentioned as well. Time was the only resource that was explicitly mentioned by respondents as a resource that influenced learning. Its effect is both positive and negative: getting time to do a task more than once to gain experience helps learning, but time pressure frustrates learning since there is only a little time for feedback and reflection.

\subsubsection{Organizational Context}

The internal context of an organization enables learning to such an extent that the organizations that are involved in the working groups need to have a commitment to learning in order for working group members to learn and for social learning to occur. Organizational commitment to learning allows representatives to deviate from the business as usual, which is beneficial for a social learning process: 'Regarding commitment to learning, I think that has been one of the major strengths of the Room 
for the River program. [ ... ] On all levels, this commitment was created' (interviewee 4). So, it is both a condition in the program and a result of the intensive collaboration processes throughout the program. Integration of knowledge and information sources is important in the context of sharing experiences, but less in sharing actual information and knowledge. The PDR would organize special training days for IPM-team members (e.g., technical manager, contract manager, location manager) to share their experiences and consequently learn from each other. The PDR also made sure that experts from the program office had cross-knowledge of all projects to prevent similar problems to occur and to transfer experiences and knowledge from one project to another. However, this points at sharing of experiences, and less to actual integration of information, which is therefore seen as less crucial. The negative score for this condition is explained by the fact that information and knowledge management was organized very well by the PDR, and there was a strong focus on facilitation of knowledge sharing to decentralized parties, so the necessity for parties to integrate their own information sources was small (see also [95] (p. 28)). Internal conflict on interests were deemed less important for social learning as they are mainly solved in the representatives' home organization, but aligning these different interests is a lesson in itself, although not a 'social lesson'. Involvement of stakeholders also contributes to learning in an ambiguous manner. Involvement of stakeholders was mainly seen as the continuity of staff and consistency in one's role and representation of the home organization. The influence of changing staff on social learning depends on the number of people that are replaced and their function; when too many people leave at once and from a specific team, the collective memory of the organization is affected, but a small change in staff every now and then results in new, fresh ideas that help to learn. It must be noted that this is also an indirect condition for social learning as this condition was researched for the internal context of an organization and not the multilevel governance structure.

\subsubsection{External Context}

Overall, external context conditions seem less important conditions for social learning compared to individual attributes and process factors. Political support is seen as both a positive influence and a negative influence on social learning; on one side, political support improves the collaborative process and creates space for a project to get going, whereas the lack of political support will create tension in the collaboration structure. A respondent formulated the role of political support like this: 'The lack of political support creates an even more urgent need to have a successful learning process I think. You are regarded more critically, which means the story you bring about the project needs to be really good. [ ... ] when you just go with what the alderman says or wants, he'll like the ideas, and be more like 'we'll just do this', instead of 'why do we want this?', and 'is this really the best option?' (interviewee 5). It shows the need to be more critical of your own work, which helps to learn. On the other hand, political support for the outcome of a design process will create commitment in the working group, which may positively influence learning.

Crisis events do not directly contribute to social learning, but project-hiccups tend to bring project teams closer together, which in turn may positively influence collaboration and social learning. Administrative procedures do not directly influence social learning, except when they slow down the process to such an extent that the collaboration process suffers from a loss of trust, which frustrates social learning. The same goes for existing laws and regulations.

\section{Concluding Remarks}

This paper aimed to identify enabling conditions for social learning in multilevel flood risk governance. We found that most of the factors identified in the conceptual framework are relevant in a direct or indirect way to the learning processes in the RftR program. So, learning processes in multilevel flood risk governance are influenced by individual attributes, collaborative arena factors, organizational factor, and external factors. However, our case study results indicate that a hierarchy of conditions can be identified.

Individual attributes and collaborative arena factors can be labeled as key, whereas organizational factors and external factors are deemed supportive. Individual attributes of participants in IFRM 
projects seem to play a major role in the social learning process, as a participants' individual attributes ultimately determine the commitment to learning.

The relative importance of individual attributes and collaborative arena factors in the social learning process is also reflected in recent work of Bentley Brymer et al. [95], who state that a change in understanding (see [21]) is foremost an individual step that takes place in multiple dimensions of their understanding. On collaborative arena or process factors, they state that factors that trigger social learning are mostly inclusiveness, extended engagement, opportunities for information exchange, and opportunities for dialogue and interaction, which correspond closely with the factors in our framework. Studies on the Quebec water governance system [96] and the Bangladesh Adaptive Delta Management [97] show findings that also point at some kind of hierarchy in the conditions for social learning. Our findings on the importance of external factors is to some extent contradicted by Johannessen et al. [98], who state that transformations in water governance are often triggered by crises. This can be explained by their focus on multiple-loop learning and the outcomes of social learning, as opposed to a focus on the process of social learning.

However, more comparative future research on conditions for social learning in different contexts should point out the validity of this hypothesis (e.g., [99]). It would, for instance, be interesting to find out whether studying social learning in the context of the German Room for the River project results in the same findings. Moreover, future studies should also pay attention to political indecisiveness and distrust and other factors hampering social learning. Such studies could result in a more validated theory on social learning in multilevel flood risk governance. A very relevant topic to do further research on is how the level of centralization of the government system, as for instance addressed by Bonasia and Lucatello [100], affects social learning processes. In the Netherlands, the governmental system is very centralized (see e.g., [101]), which leads to a clear distinction of tasks and responsibilities, whereas in, e.g., Mexico, the governmental system is much more decentralized, which affects decision making in disaster risk management [100]. Further application in different socioeconomic contexts would further help refine the framework and judge its usefulness in understanding and facilitating learning processes in flood risk governance.

The framework drawn up in this paper is based on literature on natural resources management, adaptive co-management, and social learning. As another avenue for future research, the framework may be enriched by adding additional insights or governance conditions based on stakeholder theory [102], communities of practice [103], and network governance [104].

Social learning appeared to be a process that lacks a starting point as well as a finish line. Learning itself may emerge from both success and failure. It is a constant process of balancing stakes, sharing information, and the creation of mutual trust and collective memory. Learning itself is an intangible process that may happen without the learner fully aware of it, and is mostly identifiable in retrospect. So multilevel flood risk governance asks for the setup of learning organization or platforms in which reflection and openness to change are core qualities. More specifically, we conclude that in order to enhance the changes on successful learning, such a learning organization can try to mitigate influencing conditions. Process factors and internal context can be organized as such that individuals committed to learning are attracted and are willing to participate in a collaborative process. A program directorate can trigger social learning processes by designing specific learning workshops, in which mutual trust and reflection are addressed. Besides, a learning organization can contribute to learning processes by actively taking up a bridging function in the sharing of knowledge and experiences throughout the program. Learning from past experiences is of great importance for the development of future flood risk governance programs.

Author Contributions: Conceptualization, J.d.B., C.D., F.M.; Methodology, J.d.B., C.D., F.M.; Validation, C.D., F.M.; Formal Analysis, J.d.B.; Investigation, J.d.B.; Writing-Original Draft Preparation, J.d.B., C.D. F.M.; Writing-Review \& Editing, C.D, F.M.; Supervision, C.D.

Funding: This research received no external funding. 
Acknowledgments: The authors would like to greatly acknowledge Cor Beekmans for his contribution in creating the opportunity to carry out this research project at the Rijkswaterstaat Room for the River Program and his valuable feedback and in-depth discussions on the research outcomes. We also would like to thank the anonymous reviewers for their valuable feedback on the article.

Conflicts of Interest: The authors declare no conflict of interest.

\section{References}

1. Klijn, F.; Kreibich, H.; De Moel, H.; Penning-Rowsell, E. Adaptive flood risk management planning based on a comprehensive flood risk conceptualization. Mitig. Adap. Strateg. Glob. Chang. 2015, 20, 845-864. [CrossRef] [PubMed]

2. Pahl-Wostl, C.; Becker, G.; Knieper, C.; Sendzimir, J. How multilevel societal learning processes facilitate transformative change: A comparative case study analysis on flood management. Ecol. Soc. 2013, 18, 58. [CrossRef]

3. Zevenbergen, C.; Veerbeek, W.; Gersonius, B.; Van Herk, S. Challenges in urban flood management: Travelling across spatial and temporal scales. J. Flood Risk Manag. 2008, 1, 81-88. [CrossRef]

4. Baird, J.; Plummer, R.; Moore, M.L.; Brandes, O. Introducing resilience practice to watershed groups: What are the learning effects? Soc. Nat. Resour. 2016, 29, 1214-1229. [CrossRef]

5. Bubeck, P.; Kreibich, H.; Penning-Rowsell, E.C.; Botzen, W.J.W.; De Moel, H.; Klijn, F. Explaining differences in flood management approaches in Europe and in the USA-A comparative analysis. J. Flood Risk Manag. 2017, 10, 436-445. [CrossRef]

6. Van Herk, S. Delivering Integrated Flood Risk Management: Governance for Collaboration, Learning and Adaptation; CRC Press: Delft, The Netherlands, 2014.

7. Gaddis, E.; Grellier, J.; Grobicki, A.; Hay, R.; Mirumachi, N.; Mukhtarov, F.; Rast, W. Freshwater Policy. In Global Environment Outlook-GEO-6: Healthy Planet, Healthy People; UN Environment: Nairobi, Kenya, 2019.

8. Serra-Llobet, A.; Conrad, E.; Schaefer, K. Governing for integrated water and flood risk management: Comparing top-down and bottom-up approaches in Spain and California. Water 2016, 8, 445. [CrossRef]

9. Evans, E.P.; Ashley, R.; Hall, J.W.; Penning-Rowsell, E.C.; Saul, A.; Sayers, P.B.; Watkinson, A. Foresight Flood and Coastal Defence Project: Scientific Summary: Volume I, Future Risks and their Drivers; Office of Science and Technology: London, UK, 2004; p. 366.

10. Van Herk, S.; Rijke, J.; Zevenbergen, C.; Ashley, R. Understanding the transition to integrated flood risk management in the Netherlands. Environ. Innov. Soc. Trans. 2015, 15, 84-100. [CrossRef]

11. Mukhtarov, F. The Hegemony of Integrated Water Resources Management: A study of Policy Translation in England, Turkey and Kazakhstan. Ph.D. Thesis, Central European University, Budapest, Hungary, 2009.

12. Van Herk, S.; Rijke, J.; Zevenbergen, C.; Ashley, R. Governance of integrated flood risk management to deliver large scale investment programmes: Delivery focused social learning in the Netherlands. In Proceedings of the Floodrisk 2012-2nd European Conference on Flood Risk Management, Rotterdam, The Netherlands, 20-22 November 2012.

13. Rijke, J.; van Herk, S.; Zevenbergen, C.; Ashley, R. Room for the River: Delivering Integrated River Basin Management in the Netherlands. Int. J. River Basin Manag. 2012, 10, 369-382. [CrossRef]

14. Schusler, T.M.; Decker, D.J.; Pfeffer, M.J. Social learning for collaborative natural resource management. Soc. Nat. Resour. 2003, 14, 309-326. [CrossRef]

15. Mostert, E.; Pahl-Wostl, C.; Rees, Y.; Searle, B.; Tàbara, D.; Tippett, J. Social learning in European river-basin management: Barriers and fostering mechanisms from 10 river basins. Ecol. Soc. 2007, 12, 19. [CrossRef]

16. Huitema, D.; Mostert, E.; Egas, W.; Moellenkamp, S.; Pahl-Wostl, C.; Yalcin, R. Adaptive water governance: Assessing the institutional prescriptions of adaptive (co-) management from a governance perspective and defining a research agenda. Ecol. Soc. 2009, 14, 26. [CrossRef]

17. Pahl-Wostl, C. A conceptual framework for analysing adaptive capacity and multi-level learning processes in resource governance regimes. Glob. Environ. Chang. 2009, 19, 354-365. [CrossRef]

18. Van Herk, S.; Zevenbergen, C.; Rijke, J.; Ashley, R. Collaborative research to support transition towards integrating flood risk management in urban development. J. Flood Risk Manag. 2011, 4, 306-317. [CrossRef]

19. Gerlak, A.K.; Heikkila, T. Building a theory of learning in collaboratives: Evidence from the Everglades Restoration Program. J. Public Adm. Res. Theory 2011, 21, 619-644. [CrossRef] 
20. Armitage, D.; Marschke, M.; Plummer, R. Adaptive co-management and the paradox of learning. Glob. Environ. Chang. 2008, 18, 86-98. [CrossRef]

21. Reed, M.; Evely, A.C.; Cundill, G.; Fazey, I.R.A.; Glass, J.; Laing, A.; Newig, J.; Parrish, B.; Prell, C.; Raymond, C.; et al. What is social learning? Ecol. Soc. 2010, 15, r1. [CrossRef]

22. Crona, B.I.; Parker, J.N. Learning in support of governance: Theories, methods, and a framework to assess how bridging organizations contribute to adaptive resource governance. Ecol. Soc. 2012, 17. [CrossRef]

23. Cundill, G.; Rodela, R. A review of assertions about the processes and outcomes of social learning in natural resource management. J. Environ. Manag. 2012, 113, 7-14. [CrossRef]

24. Ison, R.L.; Collins, K.B.; Wallis, P.J. Institutionalising social learning: Towards systemic and adaptive governance. Environ. Sci. Policy 2015, 53, 105-117. [CrossRef]

25. Suškevičs, M.; Hahn, T.; Rodela, R.; Macura, B.; Pahl-Wostl, C. Learning for social-ecological change: A qualitative review of outcomes across empirical literature in natural resource management. J. Environ. Plan. Manag. 2018, 61, 1085-1112. [CrossRef]

26. Mukhtarov, F.G. Intellectual history and current status of Integrated Water Resources Management: A global perspective. In Adaptive and Integrated Water Management; Springer: Berlin, Germany, 2008; pp. 167-185.

27. Berkes, F. Evolution of co-management: Role of knowledge generation, bridging organizations and social learning. J. Environ. Manag. 2009, 90, 1692-1702. [CrossRef] [PubMed]

28. Freeman, R. Learning in public policy. Oxf. Handb. Public Policy 2006. [CrossRef]

29. Muro, M.; Jeffrey, P. A critical review of the theory and application of social learning in participatory natural resource management processes. J. Environ. Plan. Manag. 2008, 51, 325-344. [CrossRef]

30. Bos, J.J.; Brown, R.R.; Farrelly, M.A. A design framework for creating social learning situations. Glob. Environ. Chang. 2013, 23, 398-412. [CrossRef]

31. Pahl-Wostl, C.; Craps, M.; Dewulf, A.; Mostert, E.; Tabara, D.; Taillieu, T. Social learning and water resources management. Ecol. Soc. 2007, 12, 5. [CrossRef]

32. Medema, W.; Light, S.; Adamowski, J. Integrating adaptive learning into adaptive water resources management. Environ. Eng. Manag. J. 2014, 13, 1801-1816.

33. Cangelosi, V.E.; Dill, W.R. Organizational learning: Observations toward a theory. Adm. Sci. Q. 1965, 10, 175-203. [CrossRef]

34. Newig, J.; Günther, D.; Pahl-Wostl, C. Synapses in the network: Learning in governance networks in the context of environmental management. Ecol. Soc. 2010, 15, 24. [CrossRef]

35. Cook, S.D.; Yanow, D. Culture and organizational learning. J. Manag. Inq. 1993, 2, 373-390. [CrossRef]

36. Knight, L. Network learning: Exploring learning by interorganizational networks. Hum. Relat. 2002, 55, 427-454. [CrossRef]

37. Senge, P. The Art and Practice of the Learning Organization; Currency Doubleday: New York, NY, USA, 1990; pp. 126-138.

38. Benson, D.; Lorenzoni, I.; Cook, H. Evaluating social learning in England flood risk management: An 'individual-community interaction' perspective. Environ. Sci. Policy 2016, 55, 326-334. [CrossRef]

39. Argyris, C.; Schön, D.A. Organizational Learning III; Addison Wesley: Boston, MA, USA, 2006.

40. Thomas, K.; Allen, S. The learning organization: A meta-analysis of themes in literature. Learn. Organ. 2006, 13, 123-139. [CrossRef]

41. March, J.G.; Olsen, J.P. The uncertainty of the past: Organizational learning under ambiguity. Eur. J. Polit. Res. 1975, 3, 147-171. [CrossRef]

42. Simon, H.A. Bounded rationality and organizational learning. Organ. Sci. 1991, 2, 125-134. [CrossRef]

43. Wenger, E. Communities of practice: Learning as a social system. Syst. Think. 1998, 9, 2-3. [CrossRef]

44. Heikkila, T.; Gerlak, A.K. Building a conceptual approach to collective learning: Lessons for public policy scholars. Policy Stud. J. 2013, 41, 484-512. [CrossRef]

45. Pahl-Wostl, C.; Sendzimir, J.; Jeffrey, P.; Aerts, J.C.J.H.; Berkamp, G.; Cross, K. Managing change toward adaptive water management through social learning. Ecol. Soc. 2007, 12, 30. [CrossRef]

46. Huntjens, P.; Pahl-Wostl, C.; Rihoux, B.; Schlüter, M.; Flachner, Z.; Neto, S.; Koskova, R.; Dickens, C.; Nabide Kiti, I. Adaptive water management and policy learning in a changing climate: A formal comparative analysis of eight water management regimes in Europe, Africa and Asia. Environ. Policy Gov. 2011, 21, 145-163. [CrossRef] 
47. Judge, T.A.; Thoresen, C.J.; Pucik, V.; Welbourne, T.M. Managerial coping with organizational change: A dispositional perspective. J. Appl. Psychol. 1999, 84, 107. [CrossRef]

48. Walker, J.H.; Armenakis, A.A.; Bernerth, J.B. Factors influencing organizational change efforts: An integrative investigation of change content, context, process and individual differences. J. Organ. Chang. Manag. 2007, 20, 761-773. [CrossRef]

49. Wanberg, C.R.; Banas, J.T. Predictors and outcomes of openness to changes in a reorganizing workplace. J. Appl. Psychol. 2000, 85, 132-142. [CrossRef] [PubMed]

50. Hofstede, G. The business of international business is culture. Int. Bus. Rev. 1994, 3, 1-14. [CrossRef]

51. Lankford, B.A.; Merrey, D.; Cour, J.; Hepworth, N. From Integrated to Expedient: An Adaptive Framework for River Basin Management in Developing Countries; International Water management Institute: Colombo, Sri Lanka, 2007.

52. Gasteyer, S.; Flora, C.B. Measuring ppm with tennis shoes: Science and locally meaningful indicators of environmental quality. Soc. Nat. Res. 2000, 13, 589-597.

53. Kusel, J.; Williams, L.; Danks, C.; Perttu, J.; Wills, L.; Keith, D.; LP Group. A Report on All-Party Monitoring and Lessons Learned from the Pilot Projects. Forest Community Research and The Pacific West. National Community Forestry Center; Technical Report No. 101-2000; Forest Community Research: Taylorsville, CA, USA.

54. Sol, J.; Beers, P.J.; Wals, A.E. Social learning in regional innovation networks: Trust, commitment and reframing as emergent properties of interaction. J. Clean. Prod. 2013, 49, 35-43. [CrossRef]

55. Pressman, J.L.; Wildavsky, A.B. Implementation: How Great Expectations in Washington are Dashed in Oakland: Or, Why It's Amazing that Federal Programs Work at All, This Being a Saga of the Economic Development Administration as Told by Two Sympathetic Observers Who Seek to Build Morals on a Foundation of Ruined Hopes; University of California Press: Berkeley, CA, USA, 1984.

56. Webster, J. Culture's influence: Towards understanding stakeholder interactions in rural water, sanitation and hygiene promotion projects. Ph.D. Thesis, Cranfield University, Cranfield, UK, 2007.

57. Rotter, J.B. Generalized expectancies for internal versus external control of reinforcement. Psychol. Monogr. Gen. Appl. 1966, 80, 1. [CrossRef]

58. Verbeeten, T. Wijs met de Waddenzee. Ph.D. Thesis, University of Utrecht, Utrecht, The Netherlands, 1999.

59. Muro, M.; Jeffrey, P. Time to talk? How the structure of dialog processes shapes stakeholder learning in participatory water resources management. Ecol. Soc. 2012, 17. [CrossRef]

60. Medema, W. Integrated water resources management and adaptive management: Shaping science and practice. PhD Thesis, Cranfield University, Cranfield, UK, 2008.

61. Dewulf, A.; Craps, M.; Bouwen, R.; Taillieu, T.; Pahl-Wostl, C. Integrated management of natural resources: Dealing with ambiguous issues, multiple actors and diverging frames. Water Sci. Technol. 2005, 52, 115-124. [CrossRef] [PubMed]

62. Van Buuren, A. Knowledge for governance, governance of knowledge: Inclusive knowledge management in collaborative governance processes. Int. Public Manag. J. 2009, 12, 208-235. [CrossRef]

63. McGinnis, M.D. Polycentric Games and Institutions: Readings from the Workshop in Political Theory and Policy Analysis; University of Michigan Press: Ann Arbor, MI, USA, 2000.

64. Geels, F.W.; Green, K. General introduction: Systems innovation and transitions to sustainability. In System Innovation and the Transition to Sustainability: Theory, Evidence and Policy; Elzen, B., Geels, F.W., Green, K., Eds.; Edward Elgar Publishing: Cheltenham, UK, 2004.

65. Keen, M.; Mahanty, S. Collaborative learning: bridging Scales and Interests, In Social learning in Environmental Management: Towards a Sustainable Future; Dyball, R., Keen, M., Eds.; Routledge: London, UK, 2012; pp. $20-38$.

66. Dyball, R.; Brown, V.; Keen, M. Towards sustainability: Five strands of social learning. In Social Learning Towards a Sustainable World; Principles, Perspectives, and Praxis; Wals, A.E.J., Ed.; Wageningen Academic Publishers: Wageningen, The Netherlands, 2007; pp. 181-195.

67. Staw, B.M.; Ross, J. Stability in the midst of change: A dispositional approach to job attitudes. J. Appl. Psychol. 1985, 70, 469. [CrossRef]

68. Bohm, D. On Dialogue; Routledge: Abingdon, UK, 2004.

69. Alvesson, M.; Sköldberg, K. Reflexive Methodology: New Vistas for Qualitative Research; Sage: Thousand Oaks, CA, USA, 2000.

70. Folke, C.; Hahn, T.; Olsson, P.; Norberg, J. Adaptive governance of social-ecological systems. Annu. Rev. Environ. Resour. 2005, 30, 441-473. [CrossRef] 
71. Keen, M.; Mahanty, S. Learning in sustainable natural resource management: Challenges and opportunities in the Pacific. Soc. Nat. Resour. 2006, 19, 497-513. [CrossRef]

72. Fernandez-Gimenez, M.; Ballard, H.; Sturtevant, V. Adaptive management and social learning in collaborative and community-based monitoring: A study of five community-based forestry organizations in the western USA. Ecol. Soc. 2008, 13, 4. [CrossRef]

73. Cash, D.W.; Adger, W.N.; Berkes, F.; Garden, P.; Lebel, L.; Olsson, P.; Pritchard, L.; Young, O. Scale and cross-scale dynamics: Governance and information in a multilevel world. Ecol. Soc. 2006, 11, 8. [CrossRef]

74. Keen, M.; Bruck, T.; Dyball, R. Social learning: A new approach to environmental management. In Social Learning in Environmental Management: Towards a Sustainable Future; Keen, M., Brown, V., Dyball, R., Eds.; Earthscan: London UK, 2005; pp. 3-21.

75. Berman, P.; McLaughlin, M.W. Federal Programs Supporting Educational Change: Vol. VIII, Implementing and Sustaining Innovations; Rand Corporation: Santa Monica, CA, USA, 1978.

76. Weick, K.E. Small wins: Redefining the scale of social problems. Am. Psychol. 1984, 39, 40. [CrossRef]

77. Measham, T. Combining people, place and learning. In Social Learning in Environmental Management: Towards a Sustainable Future; Keen, M., Brown, V.A., Dyball, R., Eds.; Routledge: Abingdon, UK, 2005.

78. Johannessen, Å.; Hahn, T. Social learning towards a more adaptive paradigm? Reducing flood risk in Kristianstad municipality, Sweden. Glob. Environ. Chang. 2013, 23, 372-381. [CrossRef]

79. Somach, S.L. Closing the Policy-Practice Gap in Water Resources Planning. J. Contemp. Water Res. Educ. $1993,90,5$.

80. Ostrom, E. Vulnerability and polycentric governance systems. IHDP Update 2001, 3, 1-4.

81. Adger, W.N.; Arnell, N.W.; Tompkins, E.L. Successful adaptation to climate change across scales. Glob. Environ. Chang. 2005, 15, 77-86. [CrossRef]

82. Pahl-Wostl, C. The importance of social learning in restoring the multifunctionality of rivers and floodplains. Ecol. Soc. 2006, 11, 10. [CrossRef]

83. Young, O. Designing environmental governance systems: The diagnostic method. In Proceedings of the Keynote at IDGEC Synthesis Conference, Bali, Indonesia, 6-9 December 2006; pp. 9-11.

84. Ostrom, E. Developing a method for analyzing institutional change. In Assessing the Evolution and Impact of Alternative Institutional Structures; Batie, S.M.N., Ed.; Routledge: Abingdon, UK, 2008.

85. Olsson, P.; Gunderson, L.; Carpenter, S.; Ryan, P.; Lebel, L.; Folke, C.; Holling, C.S. Shooting the rapids: Navigating transitions to adaptive governance of social-ecological systems. Ecol. Soc. 2006, 11, 18. [CrossRef]

86. Wurbs, R.A. Dissemination of generalized water resources models in the United States. Water Int. 1998, 23, 190-198. [CrossRef]

87. Programmadirectie Ruimte voor de Rivier. Planologische Kernbeslissing Ruimte voor de Rivier; Vastgesteld besluit: Utrecht, The Netherlands, 2006.

88. Herk, S.; van Rijke, J.; Zevenbergen, C.; Ashley, R.; Besseling, B. Adaptive co-management and network learning in the Room for the River programme. J. Environ. Plan. Manag. 2015, 58, 554-575. [CrossRef]

89. Programmadirectie Ruimte voor de Rivier. 31e Voortgangsrapportage Ruimte voor de Rivier, Verslagperiode 1 Juli-31 December 2017. Utrecht/Den Haag. 2018. Available online: https:/www.rijksoverheid.nl/documenten/ rapporten/2018/04/03/31e-voortgangsrapportage-ruimte-voor-de-rivier (accessed on 17 August 2018).

90. Hertogh, M.J.C.M.; Baker, S.; Staal-Ong, P.L.; Westerveld, E. Managing Large Infrastructure Projects: Research on Best Practices and Lessons Learnt in Large Infrastructure Projects in Europe; AT Osborne BV: Hilversum, The Netherlands, 2008.

91. Programmadirectie Ruimte voor de Rivier. 28e Voortgangsrapportage Ruimte voor de Rivier, Verslagperiode 1 Januari-30 Juni 2016. Utrecht/Den Haag. 2016. Available online: https://www.europa-nu.nl/id/vk7bkdpd1kz4/ agenda/28e_voortgangsrapportage_ruimte_voor_de (accessed on 8 August 2016).

92. Andersson Elffers Felix. 3/4 Evaluatie Ruimte voor de Rivier. Utrecht, The Netherlands. 2013. Available online: https://www.aef.nl/ruimte-voor-de-rivier-4602157c-36c7-443e-960e-e158e7aa63a1 (accessed on 8 August 2016).

93. Ten Heuvelhof, E.; Bruijn, H.; de Wal, M.; de Kort, M.; Vliet, M.; van Noordink, M.; Böhm, B. Procesevaluatie totstandkoming PKB Ruimte voor de Rivier; Berenschot: Utrecht, The Netherlands, 2007.

94. Twist, M.; van Heuvelhof, E.; ten Kort, M.; Olde Wolbers, M.; Berg, C.; van den Bressers, N. Tussenevaluatie PKB Ruimte voor de Rivier; Berenschot: Utrecht, The Netherlands, 2011.

95. Bentley Brymer, A.L.; Wulfhorst, J.D.; Brunson, M.W. Analyzing stakeholders' workshop dialogue for evidence of social learning. Ecol. Soc. 2018, 23. [CrossRef] 
96. Medema, W.; Adamowski, J.; Orr, C.J.; Wals, A.; Milot, N. Towards sustainable water governance: Examining water governance issues in Québec through the lens of multi-loop social learning. Can. Water Resour. J. 2015, 40, 373-391. [CrossRef]

97. Mutahara, M.; Warner, J.F.; Wals, A.E.; Khan, M.S.A.; Wester, P. Social learning for adaptive delta management: Tidal River Management in the Bangladesh Delta. Int. J. Water Resour. Dev. 2018, 34, 923-943. [CrossRef]

98. Johannessen, Å.; Gerger Swartling, Å.; Wamsler, C.; Andersson, K.; Arran, J.T.; Hernández Vivas, D.I.; Stenström, T.A. Transforming urban water governance through social (triple-loop) learning. Environ. Policy Gov. 2019, 29, 144-154. [CrossRef]

99. Armitage, D.; Dzyundzyak, A.; Baird, J.; Bodin, Ö.; Plummer, R.; Schultz, L. An Approach to Assess Learning Conditions, Effects and Outcomes in Environmental Governance. Environ. Policy Gov. 2018, 28, 3-14. [CrossRef]

100. Bonasia, R.; Lucatello, S. Linking Flood Susceptibility Mapping and Governance in Mexico for Flood Mitigation: A Participatory Approach Model. Atmosphere 2019, 10, 424. [CrossRef]

101. Wiering, M.; Kaufmann, M.; Mees, H.; Schellenberger, T.; Ganzevoort, W.; Hegger, D.L.T.; Larrue, C.; Matczak, P. Varieties of flood risk governance in Europe: How do countries respond to driving forces and what explains institutional change? Glob. Environ. Chang. 2017, 44, 15-26. [CrossRef]

102. Friedman, A.L.; Miles, S. Stakeholders: Theory and Practice; Oxford University Press: Oxford, UK, 2006.

103. Wenger, E. Communities of practice and social learning systems: The career of a concept. In Social Learning Systems and Communities of Practice; Springer: Berlin, Germany, 2010; pp. 179-198.

104. Sørensen, E.; Torfing, J. Introduction governance network research: Towards a second generation. In Theories of Democratic Network Governance; Palgrave Macmillan: London, UK, 2007; pp. 1-21.

(C) 2019 by the authors. Licensee MDPI, Basel, Switzerland. This article is an open access article distributed under the terms and conditions of the Creative Commons Attribution (CC BY) license (http://creativecommons.org/licenses/by/4.0/). 